efficiency under average conditions is thus raised to $65-75$ per cent by the reduction or elimination of the loss of latent heat.

The exhaust steam can be used directly in individual establishments or by what is popularly termed 'district heating' In general this means the supply of steam or hot water by means of long-distance pipe lines for the heating and general service of all types of buildings extending over a whole district or part of the area of a town.

The re-organization and improvement of the. whole fuel system of Great Britain is long overdue, and one of the most important requirements is an extensive development of district heating. To indicate the possibilities in this direction the author first discusses the two chief countries in which district-heating is employed, namely the United States and the U.S.S.R. An important point, the significance of which has not yet been generally realized, is that most of the heating in the United States and all other countries except the U.S.S.R. is carried out on thermally inefficient lines by live steam, and not by the exhaust steam, so that the total power generated in the heating stations is very small. Russia is the only country that has developed district heating upon an extensive scale by using exhaust steam from public supply electric power stations.

In the United States there are at the present time about 175 district heating companies in operation, probably supplying more than 35,000 million pounds of steam per annum. This represents only a small proportion of the total heat used in the domestic field, which requires more than 100 million tons of coal (anthracite and bituminous) per annum in addition to large amounts of oil, natural gas, coke and other fuels. District heating was made a commercial success in 1877, at his house in Chestnut Avenue, Lockport, New York, by Birdsill Holly, who founded the first steam heating company, known as the Holly Steam Combination.

The largest district heating system in the United States at present is that of the New York Steam Corporation. In 1882 the first heating station was put into service at Cortlandt Street in the Broadway area, supplying steam at $80 \mathrm{lb}$. pressure through three miles of mains. The present total length is equivalent to about ninety miles of 12 in. pipe. It has five heating stations all operated on modern steam-driven power-station lines, the largest being the Kips Bay plant at 35th Street on the East River. The pulverized-fuel equipment for the five boilers at Kips Bay consists of seven mills in an adjoining building with a total duty of 160 tons of bituminous coal an hour. An important feature of the equipment is the softening plant dealing with New York town water.

The ninety miles of mains interconnecting the five stations are of lap-welded steel with welded flanges and corrugated copper expansion joints, and numerous draining stations, capable of operating, if necessary, at $250 \mathrm{lb}$. per sq. in. pressure. Most of the insulation is 85 per cent magnesia, in blocks 2 in. thick, with canvas and tarred felt outer covering. The mains are generally laid below the pavements in concrete and tile conduits with cast iron covers, the space between the mains and walls and floor of the conduit being filled with loose slag wool.

\title{
ANTARCTIC DISCOVERIES
}

\section{By Prof. R. N. Rudmose Brown}

COME preliminary accounts of the important $S$ discoveries of the United States Antarctic Expedition, 1939-41, under Rear-Admiral R. E. Byrd, are published in the Geographical Review of July, in an article by Lieut.-Commander R. A. J. English, U.S.N. The vessels of the expedition, North Star and Bear, reached the Bay of Whales on the Ross Ice Barrier on January 11, 1940. A base to accommodate thirty-seven men was set up on the barrier within a few miles of Admiral Byrd's old base of Little America. The North Star then left to establish the east base for sixteen men in Marguerite Bay on the west coast of southern Graham Land. There she was joined by the Bear and when the unloading was completed the two vessels left for the United States not to return until the early months of 1941 , when both bases were evacuated and the whole expedition left for home.

The year in the Antarctic was well used in sledge journeys and in flights. Between Chareot Island on the east and the Ruppert Coast of Marie Byrd Land there was a gap in the known coast-line of Antaretica extending over some seventy degrees of longitude. To the south of the unknown coast-line Ellsworth had established continuity of ice-covered land with many peaks in his trans-antarctic flight of 1935 . Light was thrown on this problem by flights from the Bear on her journey from the Bay of Whales to Graham Jand, which was approximately along the parallel of $70^{\circ} \mathrm{S}$. There were several short but important flights. A flight along the Ruppert Coast to about long. $135^{\circ} \mathrm{W}$. revealed a coastal range about $4,000 \mathrm{ft}$. in height, snow-covered but with rock exposures near the coast. Far to the south the peaks of other ranges were seen. From lat. $70^{\circ} 58^{\prime}$ S., long. $105^{\circ} 33^{\prime}$ W. a flight southward again revealed such ranges lying parallel to the coast. Lastly, a flight from lat. $70^{\circ}$ $4^{\prime} \mathrm{S}$., long. $95^{\circ} 19^{\prime} \mathrm{W}$. confirmed the impression of the last flight of a mountainous peninsula immediately to the west, and the main coast-line was found to extend eastward in about lat. $73^{\circ} \mathrm{S}$. These flights have thus filled in the coast-line south of the Pacific except for a stretch of some three hundred miles between long. $115^{\circ}$ and $122^{\circ} \mathrm{W}$.

The general arrangement of the mountains in this section of Antarctica would appear to be a series of ranges more or less parallel with the coast. The Rockefeller Mountains seem to be the western end of a long range broken by many glaciers pouring northward from the high plateau of Marie Byrd Land. The highest peak discovered was Mount Hal Flood, over $10,000 \mathrm{ft}$. in altitude, in lat. $76^{\circ} 4^{\prime} \mathrm{S}$., long. $135^{\circ} 50^{\prime} \mathrm{W}$. Farther eastward there were sighted bare coastal mountains towards which the interior plateau fell. These coastal mountains extended at least as far as long. $133^{\circ} \mathrm{W}$. They suggest 
a continuation of the Andean folds of Graham Land. Incidentally also later flights supplemented Rymill's charting of Alexander I Island by adding the southern coast-line. This was determined in flights from the east base. Another of these flights mapped the western end of King George the Sixth Sound, which was also examined by one of the numerous sledge expeditions from the same base.

Some new facts in regard to the Ross Barrier seem to have been discovered. A flight from the base to lat. $81^{\circ} 8^{\prime} \mathrm{S}$., long. $176^{\circ} 15^{\prime} \mathrm{W}$. showed wide fractures in three places, not yet specified, which suggests that the ice was aground. A large snow-covered island, about thirty miles long, was noted south-east of Roosevelt Island in approximately lat. $81^{\circ} \mathrm{S}$, long. $158^{\circ} \mathrm{W}$. This, of course, would mark a land area overlain by the shelf-ice of the Barrier.

A flight was made along the northern face of the Queen Maud Range from Mount Hope near the Beardmore Glacier to long. $147^{\circ} \mathrm{W}$. In long. $175^{\circ} \mathrm{W}$. a mighty glacier nearly as large as the Beardmore Glacier was noted.

Perhaps, however, the most important result of all was achieved from the east base in a flight southward and then south-eastward across the Eternity Range of southern Graham Land to the missing western coast of the Weddell Sea. This coast has proved unapproachable by sea. Larsen, Bruce Filchner and Shackleton each were foiled by heavy packs in attempts to penetrate the western part of the Weddell Sea and between lat. $71^{\circ} \mathrm{S}$. and the Weddell or Filchner Barrier in lat. $77^{\circ}$ to $78^{\circ} \mathrm{S}$. nothing was known. The Eternity Range was photographed and followed southward to lat. $74^{\circ} 37 \mathrm{~S}$., long. $61^{\circ} 15^{\prime} \mathrm{W}$. Beyond this as far as lat. $77^{\circ} \mathrm{S}$. a south trending coastal range was visible with summits of apparently decreasing altitude. These discoveries suggest that the Weddell Sea may be wider at its southern end than had been believed. From both the west and east bases further work was done by plane and sledge, and extensive photographic surveys were made especially in Marie Byrd Land. Other aspects of the work of this highly successful expedition are not available. The article in the Geographical Review includes a preliminary small-scale map.

\section{APPOINTMENTS VACANT}

APPLICATIONs are invited for the following appointments on or before the dates mentioned:

DIRECTOR of EDUCATION-The Town Clerk, Belfast (endorsed 'Director of Education') (October 3).

SPEECH THERAPIST-The Director of Education, Leopold Street, Sheffield (October 6)

Assistant Lecturkr in MechanicaL Engineering-The Registrar, University College, Nottingham (October 6).

DEMONSTRATOR IN ZOOLOGY-Acting Head of the Department of Zoology, the University, Edgbaston, Birmingham 15 (October 7).

Lecturer in Electrical Enginenring SUbJects-The Director of Education, City Hall, Cardiff (October 8).

INSPECTOR OF SCHOOLS (WOMAN)-The Director of Education, Guildhall, Hull (October 18).

HEAD of PHYSIOLOGY DEPARTMENT-The Secretary, The Rowett Research Institute, Bucksburn, Aberdeenshire (October 31).

Lecturer with QUALIFICATIONS in Mathematios, Physios or ENGINEERING-The Principal, Technical College, Kendrick Hall, troud, Glos.

DEMONSTRATOR FOR THE BIOLOGY DEPARTMENT-The Secretary, King's College of Household and Social Science (University of London), c/o University College, Leicester.

Senior Mathimatioal Master-The Principal, King William's College, Isle of Man.

Assistant Electrical Engineer for the Federated Malay States Government Electrical Department-The Crown Agents for the Colonies, 4 Millbank, London, S.W.1 (quoting M/9769).

\section{REPORTS AND OTHER PUBLICATIONS}

(not included in the monthly Books Supplement)

\author{
Great Britain and Ireland
}

Imperial Institute: Plant and Animal Products Department. WarTime Drug Supplies and Empire Production. By Dr. M. Ashby. Pp 39. (London: Imperial Institute.) 18. net.

\section{Other Countries}

Bericht über das Geobotanische Forschungsinstitut Rübel in Zürich für das Jahr 1940. Von E. Rübel und W. Lüdi. Pp. 84. (Zürich: Geobotanische Forschungsinstitut Rübel.) [29

Proceedings of the American Philosophical Society. Vol. 84, No. 4: Symposium on Recent Advances in Psychology; Papers read before the American Philosophical Society Annual General Meeting. April 25, 1941. Pp. iii +461-564. (Philadelphia : American Philosophical Society.) 75 cents.

U.S. Department of the Interior : Geological Survey. Water-Supply Paper 872: Surface Water Supply of the United States, 1939. Part 2: South Atlantic Slope and Eastern Gulf of Mexico Basins. Pp. ix $+388+1$ plate. 40 cents. Water-Supply Paper 874 : Surface Water Supply of the United States, 1939. Part 4: St. Lawrence River Basin. Pp. vi $+213+1$ plate. 30 cents. Water-Supply Paper 876 : Surface Water Supply of the United States, 1939. Part 6:' Missouri Rive Basin. Pp. xi $+506+1$ plate. 65 cents. Water-Supply Paper 877 Surface Water Supply of the United States, 1939. Part 7: Lowe Mississippi River Basin. Pp. vii $+379+1$ plate. 45 cents. WaterSupply Paper 878: Surface Water Supply of the United States, 1939 Part 8: Western Gulf of Mexico Basins. Pp. ix $+393+1$ plate. 40 cents. (Washington, D.C. : Government Printing Office.) [29 Ceylon. Part 4: Education, Science and Art (F). Administration Report of the Director of the Colombo Museum for 1940. By P. E. P. Deraniyagala. Pp.- F4. (Colombo: Government Record

The Bankruptcy of this Scientific Age. With an Appendix: A Critical Study of the Classical Theory of Evolution. By Prof. Alfred F. Barker. Pp. iii +60. (Melbourne : John Savage and Sons Pty.,
Ltd.) Indian Central Jute Committee. Economic Research Bulletin No. 1 : World Consumption of Jute, $1938-39$ and $1939-40 . \quad$ Pp. 17. (Calcutta: Indian Central Jute Committee.) 1 rupee; 18. $6 d$. Records of the Geological Survey of India. Vol. 75, Professional Paper No. 10: The Action of Solvents on Two Indian Coals. By R. K. Dutta Roy. Pp. 18. (Calcutta: Geological Survey of India.) annas; $6 d$.

Bulletin of the Auckland Institute and Museum. No. 1: The Moa, a Study of the Dinornithiformes. By Gilbert Archey. Pp. 145 (15 plates). (Auckland: Auckland Institute and Museum.) [39

Veröffentlichungen des Geobotanischen Institutes Rübel in Zürich. Heft 17: Stratigraphie und Waldgeschichte des Wauwilermooses und ihre Verknüpfung mit den vorgeschichtlichen Siedlungen. Von H. Härri. Pp. 104. 7.50 Schw. francs. Heft 18: Die Klimaverhältnisse des Albisgebietes. Von Werner Lüdi und Balthasar Stüssi. Pp. 69. 4.20 Schw. francs. (Bern: Hans Huber.)

Nigeria. Annual Report on the Forest Administration of Nigeria for the Year 1940. Pp. 16. (Lagos: Government Printer; London : for the Year 1940. Pp. 16. (Lagos: Government Printer ; London :
Crown Agents for the Colonies.) 18.

Field Museum of Natural Hístory. Report Series, Vol. 12, No. 2 : Annual Report of the Director to the Board of Trustees for the Year 1940. (Publication 497.) Pp. 177-330 + plates 13-22. (Chicago Field Museum of Natural History.)

Science Reports of the Tokyo Bunrika Daigaku, Section B. Nos. 70-71: On the Dacrymyces-Group (Eungorum Ordinis Tremallalium Studia Monographica, III), by Yosio Kobayasi ; Über die Wirkung des Saponins auf die Spirogyra-Zellen, von G. Yamaba und Z. Araki.
Pp. $105-138+3$ plates. 60 sen. No. $74:$ On the Genera Femsjonia, Guepinia and Calocera from Japan (Fungorum Ordinis Tremallalium Studia Monographica, IV). By Y. Kobayasi. Pp. 215-228+2 plates. 35 sen. No. 76 : Studies on Japanese Aquatic Fungi, 2: The Blastocladiaceæ. By H. Indoh. Pp. 237-284. 80 sen. Nos. 79-80: Physiological Studies on Laminarin and Mannitol of Brown Alga, 2 : The Physiological Studies on Content in Eisenia bicyclis, by K. Nisizawa ; Physiological Studies on Laminarin and Mannitol of Brown Algæ, 3: Variation of their Content in Eisenia bicyclis through various Stages of Growth, by $K$. Nisizawa. Pp. 9-20. 20 sen. No. 84: The Genus
Cordyceps and its Allies. By Y. Kobayasi. Pp. 53-260. 3.20 yen. Cordyceps and its Allies. By Y. Kobayasi. Pp. 53-260. 3.20 yen.
(Tokyo: Tokyo Dunrika Daigaku.) Dominion Observatory Bulletin No. S-61: Measurement of Earthquake Intensity. By R. C. Hayes. Pp. 201B-204B. (Wellington : Government Printer.)

Palæontologia Sinica. New Series D, No. 5 (Whole Series No. 116) : The Extremity Bones of Sinanthropus pekinensis. By Prof. Franz Weidenreich. Pp. iii $+150+34$ plates. (Peking: Geological Survey of China.)

Editorial and Publishing Offices
MACMILLAN \& CO., LTD.,
ST. MARTIN'S STREET, LONDON, W.C.2.
Advertisements should be addressed to
Telephone : Whitehall 8831 Telegraphic Address : Phusis Lesquare London
T. G. Scott \& Son, Ltephone : Merstham 316

The annual subscription rate is $£ 4100$, payable in advance, Inland or Abroad All rights reserved. Registered as a Newspaper at the General Post Office 